\title{
PERBEDAAN PENGARUH KACANG TANAH (ARACHIS HYPOGAEA) REBUS DAN PANGGANG TERHADAP KADAR KOLESTEROL TOTAL PADA WANITA HIPERKOLESTEROLEMIA
}

\author{
Wahyuningsih, Yekti Wirawanni*) \\ Program Studi Ilmu Gizi Fakultas Kedokteran Universitas Diponegoro \\ Jl.Dr.Sutomo No.18, Semarang, Telp (024) 8453708, Email : gizifk@undip.ac.id
}

\begin{abstract}
Background : Hypercholesterolemia have been shown to be one of the factors associated with cardiovascular disease. Content of Peanuts (Arachis hypogaea) are MUFA (Monounsaturated fatty acid) and fiber can reduce the total cholesterol level in blood. This study purpose to determine the difference of effect boiled dan dry roasted peanuts (Arachis hypogaea) on serum total cholesterol level in women hypercholesterolemia.

Methods : This research was true experimental study with group random pre-test post-test design. Subject were women with serum total cholesterol level $\geq 200 \mathrm{mg} / \mathrm{dl}$, classified into 2 groups, treatment group 1 consume $77 \mathrm{~g}$ boiled peanuts/day (fiber 6,77 $\mathrm{g}$ and MUFA 8,39 $\mathrm{g}$ ) and treatment group 2 consume $77 \mathrm{~g}$ dry roasted peanuts/day (fiber 7,28 g and MUFA 19,93 g). Peanuts (Arachis hypogaea) was consumed during \pm 4 week. Blood was collected after an overnight fast. Serum total cholesterol level was measured with CHOD-PAP method. Shapiro Wilk was used to analyze normality of the data. The statistical analyzes include paired $t$-test, Wilcoxon, independent $t$-test and Mann Whitney.

Result : Mean of total cholesterol level before intervention treatment group boiled and dry roasted is $241,11 \mathrm{mg} / \mathrm{dl}$ and 228,56 $\mathrm{mg} / \mathrm{dl}$ respectively. Mean of total cholesterol level after intervention treatment group boiled and dry roasted is 238,67 $\mathrm{mg} / \mathrm{dl}$ and 212,22 $\mathrm{mg} / \mathrm{dl}$ respectively. There was no difference of decreased cholesterol level between first and second group $(p=0,329)$.

Conclusion: There is no difference of total cholesterol between the group treatmen boiled and dry roasted.

Keyword : Peanuts (Arachis hypogaea); serum total cholesterol; hypercholesterolemia
\end{abstract}

\section{ABSTRAK}

Latar Belakang : Hiperkolesterolemia merupakan salah satu faktor risiko terjadinya penyakit jantung dan pembuluh darah. Kacang Tanah mengandung MUFA (Mono Unsaturated Fatty Acid) dan serat yang dapat menurunkan kadar kolesterol total dalam darah. Penelitian ini bertujuan untuk mengetahui perbedaan pengaruh kacang tanah rebus dan panggang terhadap kadar kolesterol total pada wanita hiperkolesterolemia.

Metode : Jenis penelitian adalah true experimental dengan rancangan random pre-post group design. Subyek adalah wanita hiperkolestrolemia dengan kadar kolesterol total $\geq 200 \mathrm{mg} /$ dl, dibagi menjadi 2 kelompok perlakuan, yaitu kelompok 1 diberikan kacang tanah rebus $77 \mathrm{~g}$ /hari (serat 6,77 g dan MUFA 8,39 g) dan kelompok 2 diberikan kacang tanah panggang $77 \mathrm{~g}$ /hari (serat 7,28 g dan MUFA 19,93 g). Intervensi dilakukan selama \pm 4 minggu. Metode CHOD-PAP digunakan untuk menganalisis kadar kolesterol total, darah diambil setelah subyek berpuasa 10 jam. Uji normalitas menggunakan Shapiro Wilk. Analisis statistik menggunakan paired t-test, Wilcoxon, independent t-test dan Mann Whitney.

Hasil : Rerata kadar kolesterol total sebelum intervensi kelompok rebus dan panggang berturut-turut yaitu 241,11 $\mathrm{mg} / \mathrm{dl}$ dan 228,56 mg/dl. Rerata kolesterol total setelah intervensi kelompok rebus dan panggang berturut-turut yaitu 238,67 mg/dl dan 212,22 mg/dl. Tidak ada perbedaan penurunan kadar kolesterol antara kedua kelompok $(p=0,329)$.

Kesimpulan : Tidak ada perbedaan perubahan penurunan kadar kolesterol total antara kelompok rebus dan panggang $(p>0,05)$.

Kata kunci : kacang tanah; kolesterol total; hiperkolesterolemia

\section{PENDAHULUAN}

Hiperkolesterolemia merupakan kondisi dimana kadar kolesterol total dalam darah meningkat. Tingginya kadar kolesterol total merupakan salah satu faktor risiko terjadinya aterosklerosis dan penyakit kardiovaskuler. ${ }^{1,2}$

Berdasarkan World Health Organization (WHO) 2008, sebanyak 17.3 juta orang meninggal akibat penyakit kardiovaskuler dan diperkirakan meningkat menjadi 23.6 juta tahun 2030. Prevalensi penyakit kardiovaskuler tahun 2002 yaitu 28\% dan mengalami peningkatan tahun 2008 $31 \%{ }^{3-5}$ Data Nasional menurut RISKESDAS 2007 di Indonesia, prevalensi penyakit jantung sebesar $7,2 \%$ sementara prevalensi penyakit jantung di Provinsi Jawa Tengah yaitu $8,4 \%$. Sebanyak 
60,8\% kematian disebabkan karena penyakit jantung dan pembuluh darah di Kota Semarang tahun 2011.,

Pengaturan pola makan atau diet merupakan salah satu upaya dalam menurunkan kadar kolesterol total. Penurunan kadar kolesterol dilakukan dengan membatasi asupan lemak jenuh dan kolesterol serta tinggi asupan serat. Selain itu, untuk menurunkan kadar kolesterol juga dapat dilakukan dengan mengkonsumsi bahan makanan seperti kacang tanah. ${ }^{8}$

Kacang Tanah (Arachis hypogaea) merupakan salah satu komoditi tanaman pangan memiliki kandungan zat gizi yang tinggi. Kandungan kacang tanah yang memiliki potensi menyebabkan hipokolesterolemik antara lain, MUFA (Mono Unsaturated Fatty Acid), PUFA (Poly Unsaturated Fatty Acid) dan serat. ${ }^{1}$ Efek penurunan kadar LDL oleh MUFA dan PUFA dikaitkan dengan bertambahnya aktivitas reseptor LDL. ${ }^{9}$ Diet tinggi MUFA $20 \%$ dari total kalori dapat menurunkan kolesterol total $10 \%$ dan LDL $14 \%$ serta trigliserida $13 \% .{ }^{10}$ Asupan serat dapat menurunkan kolesterol yaitu dengan mengikat asam empedu untuk dikeluarkan bersama dengan feses. ${ }^{11}$ Asupan serat yang direkomendasikan oleh American Dietetic Association (ADA) yaitu 20-35 g per hari. ${ }^{12}$

Menurut penelitian di Iran, pemberian kacang tanah panggang sebanyak $77 \mathrm{~g}$ per hari pada laki-laki hiperkolesterolemia selama empat minggu terjadi penurunan kadar kolesterol total secara signifikan sebesar 2,6\% $\quad(255,0 \quad \mathrm{mg} / \mathrm{dl}$ menjadi $248,3 \mathrm{mg} / \mathrm{dl}$ ) dan kadar kolesterol LDL $4 \%(170,0 \mathrm{mg} / \mathrm{dl}$ menjadi $163,2 \mathrm{mg} / \mathrm{dl})$ serta meningkatkan kadar kolesterol HDL (High Density Lipoprotein) $14,3 \% \quad(33,5 \mathrm{mg} / \mathrm{dl}$ menjadi 38,3 $\mathrm{mg} / \mathrm{dl}) .{ }^{13}$ Sementara penelitian yang dilakukan di Amerika, pemberian kacang tanah panggang sebanyak 35-68 g per hari pada wanita postmenopause hiperkolesterolemia selama enam bulan juga signifikan menurunkan kadar kolesterol total $10 \%(264 \mathrm{mg} / \mathrm{dl}$ menjadi $238 \mathrm{mg} / \mathrm{dl})$ dan kolesterol LDL $12 \%$ (182 mg/dl menjadi 161 ,g/dl). ${ }^{14}$

Penelitian mengenai pemberian kacang tanah panggang pada laki-laki hiperkolesterolemia selama empat minggu sudah pernah dilakukan, namun penelitian tentang pemberian kacang tanah rebus belum dilakukan. Hal ini, mendorong peneliti melakukan penelitian tentang perbedaan pengaruh kacang tanah rebus dan panggang terhadap kadar kolesterol total pada wanita hiperkolesterolemia.

\section{METODE}

Penelitian ini merupakan penelitian random true experimental dengan rancangan prepost group design. Variabel bebas dalam penelitian ini adalah kacang tanah rebus dan panggang $77 \mathrm{~g}$, sementara variabel terikat adalah kadar kolesterol total.

Subyek penelitian pada penelitian ini adalah karyawati kantor Gedung Pandanaran yang terdiri dari Dinas Kebudayaan dan Pariwisata, Kelautan dan Perikanan, Arsip Perpustakaan, Koperasi Kota Semarang dan karyawati kantor Sekretariat Daerah Provinsi Jawa Tengah Semarang, dengan kriteria inklusi memiliki kadar kolesterol total $\geq 200 \mathrm{mg} / \mathrm{dl}$, berusia minimal 30 tahun, belum menopause, tidak sedang mengkonsumsi obat antihiperlipidemia dan tidak dalam keadaan sakit atau perawatan dokter berkaitan dengan penyakit jantung koroner, diabetes melitus, hipertensi, dan penyakit kronik lainnya.

Perhitungan besar sampel menggunakan rumus uji hipotesis terhadap rerata dua populasi independen. Jumlah subyek saat melakukan skrining awal sebanyak 50 subyek dengan menggunakan metode consecutive sampling. Namun, setelah dilihat Umur, Indeks Massa Tubuh (IMT) dan Kolesterol total tinggi yang sesuai kriteria inklusi didapatkan 26 subyek. Sedangkan 24 subyek lainnya tidak bersedia mengikuti intervensi kacang tanah. Sehingga jumlah sampel yang memenuhi syarat yaitu 26 orang. Setelah mendapat persetujuan dari subyek melalui inform consent, peneliti langsung melakukan simple random sampling untuk membagi menjadi dua kelompok, masing- masing kelompok terdiri dari 13 subyek. Intervensi dilakukan selama \pm 4 minggu dengan dosis $77 \mathrm{~g}$ kacang tanah rebus dan panggang. Saat intervensi berlangsung, sebanyak 8 subyek mengundurkan diri (drop out) sehingga tersisa 18 subyek. Sebagian besar subyek mengundurkan diri karena sakit dan ada dinas luar kota sehingga tidak memungkinkan melanjutkan intervensi. Jumlah sampel dalam penelitian ini adalah 9 subyek tiap kelompok perlakuan. Pencatatan asupan makan dilakukan sebelum dan selama intervensi berlangsung menggunakan formulir food recall 24 jam. Data asupan makan subyek dianalisis menggunakan program nutrisurvey 2005. Pada hari ke-29 dilakukan pengambilan darah kembali untuk mengetahui perubahan kadar kolesterol total setelah diberikan intervensi. 
Kadar kolesterol total dianalisis dengan pemeriksaan labolatorium Swasta dengan menggunakan metode Cholesterol Oxidase Phenol Aminoantipyrin (CHOD-PAP). Darah diambil oleh peneliti setelah subyek berpuasa selama \pm 10 jam. Uji normalitas menggunakan Shapiro-Wilk dimana jumlah sampel $<50$ orang. Karakteristik subyek dianalisis menggunakan analisis deskriptif. Perbedaan kadar kolesterol total sebelum dan sesudah menggunakan paired t-test untuk data berdistribusi normal dan uji Wilcoxon untuk data berdistribusi tidak normal. Perbedaan kadar kolesterol total antara dua kelompok perlakuan dianalisis menggunakan independent t-test untuk data berdistribusi normal dan uji Mann-Whitney untuk data berdistribusi tidak normal.

\section{HASIL PENELITIAN \\ Karakteristik Subjek}

Karakteristik subjek yang terdiri dari gambaran umur, status gizi dan kadar kolesterol total disajikan dalam tabel 1.

Tabel 1. Karakteristik subyek

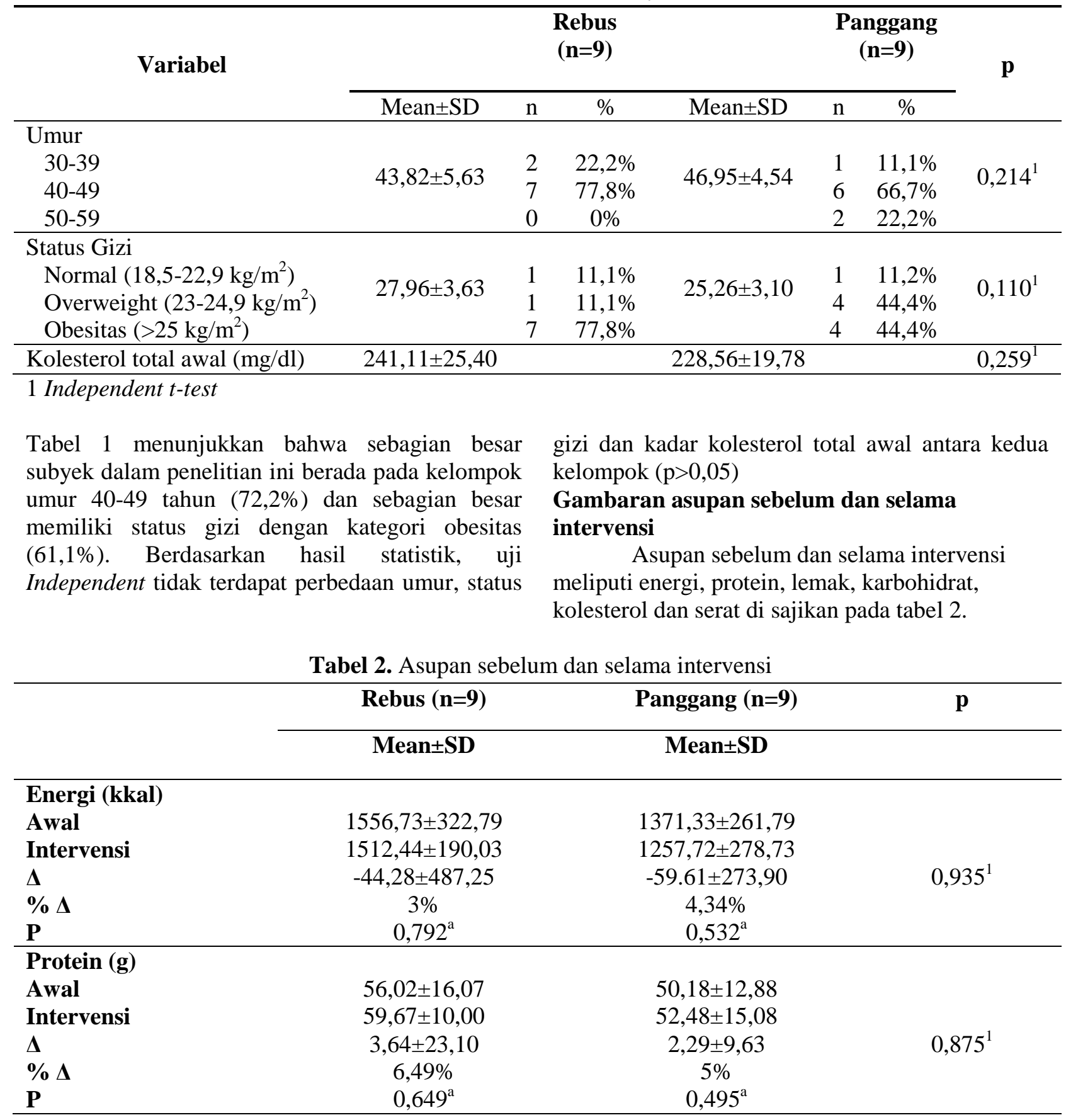




\begin{tabular}{|c|c|c|c|}
\hline \multicolumn{4}{|l|}{ Lemak (g) } \\
\hline Awal & $50,97 \pm 11,66$ & $49,87 \pm 9,74$ & \multirow{5}{*}{$0,544^{1}$} \\
\hline Intervensi & $67,00 \pm 20,16$ & $60,02 \pm 13,28$ & \\
\hline$\Delta$ & $16,03 \pm 21,93$ & $10,14 \pm 18,09$ & \\
\hline$\% \Delta$ & $31,44 \%$ & $20,33 \%$ & \\
\hline $\mathbf{P}$ & $0,060^{\mathrm{a}}$ & $0,131^{\mathrm{a}}$ & \\
\hline \multicolumn{4}{|c|}{ Karbohidrat (g) } \\
\hline Awal & $188,83 \pm 50,24$ & $146,75 \pm 36,57$ & \multirow{5}{*}{$0,449^{1}$} \\
\hline Intervensi & $145,12 \pm 34,30$ & $122,02 \pm 26,04$ & \\
\hline$\Delta$ & $-43,70 \pm 68,43$ & $-24,73 \pm 26,21$ & \\
\hline$\% \Delta$ & $23,14 \%$ & $16,85 \%$ & \\
\hline $\mathbf{P}$ & $0,092^{\mathrm{a}}$ & $0,220^{\mathrm{a}}$ & \\
\hline \multicolumn{4}{|c|}{ Kolesterol (mg) } \\
\hline Awal & $210,66 \pm 120,79$ & $190.85 \pm 78.99$ & \multirow{5}{*}{$0,649^{1}$} \\
\hline Intervensi & $230,95 \pm 88,36$ & $180.89 \pm 48.85$ & \\
\hline$\Delta$ & $20,88 \pm 176,91$ & $-9,96 \pm 92,08$ & \\
\hline$\% \Delta$ & $10 \%$ & $5,21 \%$ & \\
\hline $\mathbf{p}$ & $0,594^{\mathrm{b}}$ & $0,754^{\mathrm{a}}$ & \\
\hline \multicolumn{4}{|l|}{ Serat (g) } \\
\hline Awal & $8,58 \pm 3,07$ & $8,36 \pm 3,78$ & \multirow{5}{*}{$0,708^{1}$} \\
\hline Intervensi & $10,69 \pm 1,88$ & $11,09 \pm 3,39$ & \\
\hline$\Delta$ & $2,10 \pm 4,15$ & $2,72 \pm 2,64$ & \\
\hline$\% \Delta$ & $24,47 \%$ & $33 \%$ & \\
\hline $\mathbf{p}$ & $0,168^{\mathrm{a}}$ & $0,015^{\mathrm{a}^{* *}}$ & \\
\hline
\end{tabular}

Tabel 2 menunjukkan bahwa :

- Hasil uji independent, tidak terdapat perbedaan perubahan rerata asupan energi, protein, karbohidrat, lemak, kolesterol dan serat antara kedua kelompok ( $>0,05)$.

- Uji paired, tidak terdapat perbedaan rerata asupan energi, protein, lemak, karbohidrat dan kolesterol sebelum dan selama intervensi
( $p>0,05)$. Namun, terdapat perbedaan signifikan rerata asupan serat sebelum dan selama intervensi pada kelompok panggang $(\mathrm{p}<0,05)$.

Gambaran Asupan lemak

Asupan lemak yang terdiri dari lemak jenuh dan lemak tidak jenuh meliputi MUFA dan PUFA sebelum dan selama intervensi.

Tabel 3. Asupan lemak sebelum dan selama intervensi

\begin{tabular}{lccc}
\hline & Rebus $(\mathrm{n}=9)$ & Panggang $(\mathrm{n}=9)$ & $\mathrm{P}$ \\
\cline { 2 - 4 } & Mean \pm SD & Mean \pm SD & \\
\hline Lemak Jenuh (g) & $20,71 \pm 4,94$ & $18,03 \pm 6,72$ & \\
Awal & $28,80 \pm 6,85$ & $24,47 \pm 5,91$ & \\
Intervensi & $8,08 \pm 10,44$ & $6,44 \pm 9,22$ & $0,729^{1}$ \\
$\boldsymbol{\Delta}$ & $39 \%$ & $36 \%$ & \\
$\mathbf{\%} \boldsymbol{\Delta}$ & $0,049^{\text {*** }}$ & $0,069^{\mathrm{a}}$ & \\
$\mathbf{p}$ & & & \\
\hline MUFA (g) & $14,62 \pm 3,62$ & $15,29 \pm 2,14$ & $0,745^{1}$ \\
Awal & $14,87 \pm 4,72$ & $16,54 \pm 5,81$ & \\
Intervensi & $0,25 \pm 6,83$ & $1,24 \pm 6,30$ & \\
$\boldsymbol{\Delta}$ & $2 \%$ & $8,10 \%$ & \\
$\mathbf{\%} \boldsymbol{\Delta}$ & $0,907^{\mathrm{a}}$ & $0,569^{\mathrm{a}}$ & \\
$\mathbf{P}$ & & & \\
\hline
\end{tabular}




\begin{tabular}{|c|c|c|c|}
\hline \multicolumn{4}{|l|}{ PUFA (g) } \\
\hline Awal & $11,77 \pm 5,71$ & $13,29 \pm 2,45$ & \\
\hline Intervensi & $16,38 \pm 6,81$ & $16,65 \pm 9,63$ & \\
\hline$\Delta$ & $4,61 \pm 10,07$ & $3,35 \pm 9,27$ & $0,787^{1}$ \\
\hline$\% \Delta$ & $39,16 \%$ & $25,20 \%$ & \\
\hline $\mathbf{p}$ & $0,207^{\mathrm{a}}$ & $0,309^{\mathrm{a}}$ & \\
\hline
\end{tabular}

Hasil tabel 3, menunjukkan bahwa:

- Uji Independent, tidak terdapat perbedaan rerata asupan lemak jenuh, MUFA dan PUFA antara kedua kelompok ( $p>0,05)$.

- Uji paired, tidak terdapat perbedaan rerata asupan MUFA dan PUFA sebelum dan selama intervensi antara kedua kelompok ( $>00,05)$. Namun, terdapat perbedaan signifikan asupan lemak jenuh sebelum dan selama intervensi pada kelompok rebus $(\mathrm{p}<0,05)$. Hal ini diduga menjadi faktor risiko tingginya kadar kolesterol total.

Perbedaan pengaruh kacang tanah rebus dan panggang terhadap kadar kolesterol total

Perbedaan pengaruh kacang tanah rebus dan panggang terhadap kadar kolesterol total awal dan akhir disajikan pada tabel 4 .

Tabel 4. Perbedaan pengaruh kacang tanah rebus dan panggang terhadap kadar kolesterol total

\begin{tabular}{cccc}
\hline Variabel & Rebus $(\mathbf{n}=9)$ & Panggang $(\mathbf{n}=9)$ & \\
\cline { 2 - 3 } & Mean \pm SD & Mean \pm SD & p \\
\hline Kolesterol total $(\mathrm{mg} / \mathrm{dl})$ & $241,11 \pm 25,40$ & $228,56 \pm 19,78$ & $0,259^{1}$ \\
Awal & $238,67 \pm 45,95$ & $212,22 \pm 40,53$ & $0,214^{1}$ \\
Akhir & $-2,44 \pm 29,10$ & $-16,34 \pm 29,39$ & $0,329^{1}$ \\
$\Delta$ & $1 \%$ & $7 \%$ & \\
$\Delta \%$ & $0,807^{*}$ & $0,134^{*}$ & \\
p & &
\end{tabular}

*paired $t$ - test 1 Independent $t$-test

Hasil analisa statistik tabel 4:

Uji Independent menunjukkan, bahwa tidak terdapat rerata kadar kolesterol total antara kedua kelompok ( $>>0,05)$.

- Uji paired menunjukkan, bahwa tidak terdapat perbedaan rerata kadar kolesterol total sebelum dan setelah intervensi pada kelompok rebus dan panggang $(p>0,05)$. Namun, secara deskriptif terjadi penurunan kadar kolesterol total sebesar $1 \%$ pada kelompok rebus dan $7 \%$ pada kelompok panggang.

\section{PEMBAHASAN}

Karakteristik subjek dalam penelitian ini adalah wanita hiperkolesterolemia yang belum mengalami menopause. Sebagian besar subjek berada pada kelompok umur 40-49 tahun. Risiko hiperkolesterolemia pada wanita meningkat seiring bertambahnya usia dan berat badan. Pada usia subur, wanita terlindungi oleh hormon estrogen yang berperan dalam mencegah terbentuknya plak arteri. Kelompok umur 40-49 tahun memiliki risiko lebih besar dalam peningkatan kadar kolesterol total dibandingkan wanita usia produktif. Wanita yang memasuki masa pre menopause hingga menopause, terjadi penurunan produksi hormon estrogen di dalam tubuh, yang dapat meningkatkan risiko terjadinya peningkatan kadar kolesterol. ${ }^{15}$

Status gizi kategori obesitas juga merupakan faktor yang mempengaruhi kadar kolesterol. Pada penelitian ini, sebagian besar status gizi subjek berada pada kategori obesitas (IMT $>25 \mathrm{~kg} / \mathrm{m}^{2}$ ). Obesitas terjadi akibat akumulasi jaringan lemak berlebihan. Jaringan adiposa yang berlebih mempengaruhi terjadinya penyakit jantung melalui beberapa faktor risiko seperti tingginya kadar kolesterol. Pada penderita obesitas sering terjadi gangguan metabolisme lipoprotein, sehingga terdapat kecenderungan adanya peningkatan kadar kolesterol. ${ }^{16,17}$

Berdasarkan hasil analisis statistik, tidak terdapat perbedaan yang signifikan terhadap kadar kolesterol total sebelum dan setelah intervensi antara kedua kelompok ( $>>0,05)$. Namun, secara deskriptif terjadi penurunan kadar kolesterol total 
sebelum dan setelah intervensi kelompok rebus sebesar $1 \%(241,11 \mathrm{mg} / \mathrm{dl}$ menjadi $238,68 \mathrm{mg} / \mathrm{dl})$ dan kelompok panggang sebesar $7 \%(228,56 \mathrm{mg} / \mathrm{dl}$ menjadi 212,22 $\mathrm{mg} / \mathrm{dl})$. Hal ini tidak sejalan dengan penelitian yang telah dilakukan di Iran pada penderita hiperkolesterolemia yang menunjukkan bahwa pemberian kacang tanah selama empat minggu secara signifikan menurunkan kadar kolesterol total 2,6\% (255,0 $\mathrm{mg} / \mathrm{dl}$ menjadi $248,3 \mathrm{mg} / \mathrm{dl}$ ) dan kadar kolesterol LDL $4 \%(170,0 \mathrm{mg} / \mathrm{dl}$ menjadi $163,2 \mathrm{mg} / \mathrm{dl})$ serta meningkatkan kadar kolesterol HDL 14,3\% (33,5 $\mathrm{mg} / \mathrm{dl}$ menjadi $38,3 \mathrm{mg} / \mathrm{dl}) .{ }^{13}$ Penelitian lain yang dilakukan di Amerika, menunjukkan pemberian kacang tanah panggang sebanyak 35-68 g per hari pada wanita postmenopause hiperkolesterolemia selama enam bulan juga secara signifikan menurunkan kadar kolesterol total 10\% (264 mg/dl menjadi $238 \mathrm{mg} / \mathrm{dl}, \mathrm{P} \leq 0,01)$ dan kolesterol LDL 12\% (182 mg/dl menjadi $161, \mathrm{~g} / \mathrm{dl}){ }^{14}$ Tiap penurunan $1 \%$ kadar kolesterol kemungkinan menurunkan risiko terkena penyakit kardiovaskuler sebanyak $2-3 \% .^{18}$

Berdasarkan hasil penelitian ini, faktorfaktor yang mempengaruhi tingginya kadar kolesterol total antara lain asupan tinggi lemak jenuh dan kolesterol. Peran asam lemak adalah meningkatkan sintesis kolesterol dan LDL (Low Density Lipoprotein) sehingga berpengaruh dalam meningkatkan kadar kolesterol dalam darah. Asam lemak jenuh dapat menyebabkan terbentuknya partikel VLDL. Dimana trigliserida banyak terdapat di lipoprotein VLDL. Apabila VLDL meningkat, maka LDL juga meningkat sehingga dapat meningkatkan kadar kolesterol. ${ }^{9}$

Asupan tinggi kolesterol juga merupakan penyebab peningkatan kadar kolesterol total. Asupan kolesterol sebelum dan selama intervensi terjadi peningkatan pada kelompok rebus yaitu $10 \%$, sedangkan pada kelompok panggang terjadi penurunan $5,2 \%$. Hal ini menyebabkan penurunan kadar kolesterol total pada kelompok rebus yaitu $1 \%$ dibandingkan kelompok panggang $7 \%$. Sebagian besar jumlah kolesterol dalam tubuh berasal dari sintesis (sekitar $700 \mathrm{mg}$ per hari), sisanya berasal dari asupan makanan sehari-hari. Asupam kolesterol dan lemak tak jenuh dapat meningkatkan kadar kolesterol LDL dan aktivitas reseptor LDL. ${ }^{1}$

Faktor yang berpengaruh terhadap menurunkan kadar kolesterol total yaitu asupan tinggi MUFA, PUFA dan serat. Asupan MUFA meningkat pada kelompok panggang sebesar $8 \%$ dibandingkan kelompok rebus $2 \%$. Hal ini menyebabkan penurunan kadar kolesterol total pada kelompok rebus $1 \%$ dibandingkan kelompok panggang $7 \%$. Efek penurunan kadar kolesterol LDL oleh MUFA dan PUFA berkaitan dengan bertambahnya jumlah aktivitas reseptor LDL.9,18 Diet tinggi MUFA 20\% dari total kalori dapat menurunkan kolesterol total $10 \%$ dan LDL $14 \%$ serta trigliserida $13 \% .^{10}$

Asupan tinggi serat juga merupakan faktor yang dapat menurunkan kadar kolesterol. Hasil asupan recall, menunjukkan bahwa terjadi peningkatan asupan serat sebesar 32,6\% secara signifikan pada kelompok panggang. Hal ini menyebabkan penurunan kadar kolesterol total pada kelompok panggang 7\% dibandingkan kelompok rebus $1 \%$. Namun, jumlah serat yang dikonsumsi subjek masih tergolong rendah. Asupan serat yang direkomendasikan oleh American Dietetic Association (ADA) yaitu 20-35 g per hari. ${ }^{12}$ Peran serat dalam menurunkan kadar kolesterol yaitu mengikat asam empedu dan meningkatkan pengeluarannya melalui feses. Kemampuan serat dalam mengikat asam empedu mengakibatkan adanya peningkatan jumlah kolesterol yang digunakan untuk mensintesis asam empedu dan menurunnya jumlah kolesterol yang digunakan untuk mensintesis lipoprotein. Garam empedu yang terikat pada serat tidak dapat direabsorbsi kembali melalui siklus enterohepatik dan akan disekresi melalui feses, akibatnya terjadi penurunan jumlah garam empedu yang menuju ke hati. Penurunan ini akan meningkatkan pengambilan kolesterol untuk disintesis kembali menjadi asam empedu yang baru yang berakibat pada penurunan kadar kolesterol dalam darah. Serat juga dapat menghambat sintesis kolesterol dengan melalui proses fermentasi serat oleh bakteria yang ada di kolon, sehingga menghasilkan propionat, asetat, dan butirat (asam lemak rantai pendek). Asam lemak rantai pendek ini dapat menghambat aktivitas HMG CoA reduktase yang merupakan suatu enzim untuk mensintesis kolesterol. Hal ini menyebabkan menurunnya sintesis kolesterol. ${ }^{9,11}$

\section{KESIMPULAN}

Tidak ada perbedaan perubahan penurunan kadar kolesterol total antara kelompok rebus dan panggang terhadap pada wanita hiperkolesterolemia.

\section{DAFTAR PUSTAKA}

1. Krummel DA. Medical Nutrition Therapy in Cardiovascular Disease. In Mahan LK, Escott- 
stump S. Krause's food, Nutrition, and Diet Therapy. 13th ed. Philadelphia: WB Saunders Company;2012.

2. Veghari G, Mehdi S. Obesity and risk of hypercholesterolemia in Iranian northern adults. ARYA Atheroscler.2013; Vol 9: 1.

3. World Health Organization. The impact of chronic disease in Indonesia. Facing the facts 2002 [cited 2013 March 02]. Available from URL:

http://www.who.int/chp/chronic_disease_repor t/media/impact/indonesia.pdf

4. World Health Organization. Indonesia. Non Communicable Disease Country Profiles 2011[cited 2013 March 02]. Available from URL:

http://www.who.int/nmh/countries/idn_en.pdf

5. World Health Organization. Indonesia. Global Atlas on cardiovascular disease prevention and control 2011[cited 2013 March 07]. Available from URL: http://www.who.int/publications/2011/9789241 564373 en.pdf

6. Laporan Hasil Riset Kesehatan Dasar (RISKESDAS) Nasional 2007.

7. Dinas Kesehatan Kota Semarang. Laporan Kematian Akibat Penyakit Tidak Menular 2011.

8. Kreisberg RA, Oberman A. Medical management of hyperlipidemia/ dislipidemia. The Journal of Clinical Endocrinilogy and Metabolism. 2003;88(6):2445-61.

9. Mayes, PA. Sintesis, Transport dan Ekskresi Kolesterol. Dalam : Murray RK, Granner DK, Mayes PA, Rodwell VW, editors. Biokimia Harper. Edisi 27. Jakarta: Penerbit Buku Kedokteran EGC; 2009.p.239-49

10. Etherton-Kris PM, Thomas AP, Ying W, Rebecca LH, Kristin M, Valerie F, et al. Highmonounsaturated fatty acid diets lower both plasmma cholesterol and triacyglycerol consentrations. AJCN; USA. 1999.70:1009-15.

11. Gropper SS, Jack LS, James LG. Fiber. Advanced Nutrition and Human Metabolism. Edisi kelima. USA;2009.p.107-123.

12. Dreher ML. Dietary Fiber Overview. Indiana : Mead Johnson Nutritionals/Bristol-Myers Squibb Company, Evansville. 2001.

13. Ghadimi MN, Masaud K, Alireza A, Majid M, Gail H. Peanut consumption and cardiovascular risk. Public Health Nutrition. Iran: 13(10).p.1581-1586.

14. Byrne DJ, David A. Knauft, Rachel B. Shireman. Low Fat-Monounsaturated Rich Diets Containing High-Oleic Peanuts Improve Serum Lipoprotein Profiles. Eur J Nutr 1997; p.687-691.

15. Soeharto I. Pengaruh Usia dan Gender terhadap Kolesterol. Dalam : Serangan Jantung dan
Stroke. Jakarta : PT Gramedia Pustaka Utama; 2004.hal.168-178

16. Fletcher B, Berra K, Ades P, Braun LT, Burke LE, Durstine JL, et al. Managing Abnormal Blood Lipids, a Collaborative Approach. Circulation. 2005;112:3184-3209.

17. Soegondo Sidartawan, Reno Gustaviani. Obesitas. Dalam: Sudoyo Aru W, Bambang Setiyohadi, Idrus Alwi, Marcellus SK, Siti S, editor. Buku Ajar Ilmu Penyakit Dalam Jilid III. Edisi keempat. Jakarta: Penerbit Departemen Ilmu Penyakit Dalam Fakultas Kedokteran UI; 2007.p.1919-1925.

18. Gropper SS, Jack LS, James LG. Lipid. Advanced Nutrition and Human Metabolism. Edisi kelima. USA;2009.p.131-168. 